\title{
KARAKTER LAKI-LAKI DALAM PROGRAM TELEVISI (ANALISI RESEPSI PERAN PRIA SEBAGAI PEKERJA RUMAH TANGGA DALAM PROGRAM SITKOM DUNIA TERBALIK DI RCTI)
}

\author{
Berlian Ilham \\ Prodi Ilmu Komunikasi, Universitas Muhammadiyah Surakarta \\ Email: berliilham@gmail.com
}

\begin{abstract}
ABSTRAK
Kontruksi media yang menampilkan karakter laki-laki disetiap tayangan sinetron cukup beragam dalam kompleks mengenai maskulin dan feminin. Penelitian ini bertujuan untuk mencaritahu bagaimana khalayak Indonesia menciptakan persepsi mengenai karakter laki-laki dalam televisi dengan dipengaruhi adanya perbedaan latar belakang, perbedaan gender, dan budaya. Analisis resepsi yang peneliti gunakan untuk melihat peran khalayak sebagai penonton aktif dalam mengintepretasikan karakter laki-laki yang ditampilkan menurut resepsi mereka. Peneliti menggunakan metode kualitatif deskriptif dengan melakukan Focus Group Discussion (FGD). Hasil dari penelitian ini menunjukkan bahwa kualifikasi meliputi pengalaman dan budaya yang mempengaruhi bagaimana cara pandang mereka dalam memaknai konstruksi media mengenai karakter laki-laki yang ditampilkan. Menurut Fokus Grup A dan Fokus Grup B media sekarang ini menampilkan karakter laki-laki yang bisa dikatakan cukup berlebihan dan memilih meoposisikan segala sesuatu kontruksi media dengan pengalaman hidup yang dilalui dan dari sudut pandang budayanya.
\end{abstract}

Kata kunci : Analisis resepsi, budaya partiarki, media, sinetron, stereotip.

\begin{abstract}
Media construction that shown male characters in every sinetron impressions quiete diverse about masculine and feminine. The purpose of the research is to find out how the Indonesian create their perception about the male characters on television program that is affected by difference background, gender, and culture. The reception analysis which the researcher use to see the role of audiences as the active viewer in interpreting the male characters shown on the program according to their reception. The researcher use the descriptive qualitative method by using focus group discussion (FGD). The result of the research indicates qualification that covered experiences and culture that affect how their perception in interpretes media construction about male characters that shown. According to the focus of group $A$ and $B$ is the media recently show up the male characters quiete excessive and choose to positioning all of the thing about media constructions with experiences and culture perspectives.
\end{abstract}

Keyword: Reception analysis, patriarchal system, media, sinetron, stereotype.

\section{A. PENDAHULUAN}

Televisi sebagai salah satu media massa yang populer di Indonesia yang memiliki potensi dalam pembentukan identitas kultural melalui beragam representasi narasi, images, dan tanda-tanda (Dalyono, 2010). Namun acara-acara televisi yang kurang lebih seragam, nampak televisi menekankan pada pembentukan dan penguatan stereotip yang berlaku dalam masyarakat terhadap kelompok gender, etnik, agama, dan status sosial ekonomi.

Gender merupakan seperangkat peran untuk memberitahukan kepada orang lain 
bahwa kita adalah feminin dan maskulin (Mosse dalam Karlina, 2008). Maskulin yang diidentikan dengan kekuasaan, agresif, dan kuat, sedangkan feminin yang diidentikan dengan sikap lemah, penakut, penurut dan ketergantung dengan orang lain, membuat maskulin dan feminin dapat dimiliki oleh lakilaki atau perempuan. Proses ini mengarah kepada pembagian kerja di sektor domestik serta sektor publik yang lebih seimbang antara laki-laki dan perempuan.

Maskulin yang ada pada diri laki-laki membuat laki-laki memposisikan dirinya lebih tinggi daripada perempuan baik sektor publik maupun dalam rumah tangga (Lestari \& Putri, 2015). Bahkan dalam budaya partiarki menempatkan laki-laki sebagai dominan dan menempatkan perempuan sebagai subordinat. Ideologi patriarki mencirikan bahwa laki-laki merupakan kepala rumah tangga, pencari nafkah yang terlihat dalam pekerjaan produktif di luar rumah maupun sebagai penerus keturunan (Sihite dalam Lestari \& Putri, 2015). Hal tersebut disebabkan budaya partiarki membentuk sikap peran gender tradisional kepada masyarakat. Bahkan dalam sikap peran gender tradisional, laki-laki pun dianggap lebih superior (Olson \& Defrain dalam Lestari \& Putri, 2015).

Berdasarkan pandangan budaya jawa tradisional, seorang perempuan/istri, sektor kekuasaannya hanyalah sebatas hal domestik seperti memasak, mencuci, dan merawat anak. Sedangkan laki-laki/suami harus bisa memenuhi kebutuhan sehari-hari dalam keluarga (Budiati, 2010). Perempuan memiliki kemampuan managerial yang mengandung arti melaksanakan pekerjaan untuk mengatur (Sukesi dalam Yuniastusi, 2014).

Terkait dengan peran ekonomi dalam keluarga, di Indonesia fenomena migrasi internasional dalam konteks migrasi tenaga kerja Indonesia (TKI), sudah menjadi bagian integral dari kehidupan ekonomi dalam mencari pekerjaan, merubah kehidupan yang lebih baik dan merubah ekonomi keluarga, menjadi salah satu alasan penting dalam migrasi (Raharto, 2017). Hal ini membuat perempuan dalam keterbatasan ekonomi keluarganya, dapat jadikan ini peluang untuk membantu perekonomian dikeluarganya. Pekerjaan sebagai TKI/TKW sampai saat ini masih dianggap yang lebih menarik (Yuniastuti, 2014).

Budaya partiarki yang seharusnya lakilaki berada diposisi dominan, kini laki-laki dapat diposisikan disubordinat. Hal ini terjadi pada sinetron komedi Dunia Terbalik yang diproduksi oleh RCTI. Dunia Terbalik merupakan judul program sinetron komedi yang berfokus kepada warga Ciraos yang hampir setiap warganya memberangkatkan istrinya untuk menjadi tenaga kerja wanita (TKW) di luar negri atau menjadi pembatu rumah tangga di dalam negeri (http:// mncpictures.com).

Sinetron komedi yang disutradarai lip S. Hanan ini memiliki keunikan tersendiri di dalam sinetron komedinya. Budaya partiarki tidak ditampilkan seperti di sinetron lainnya yang menampilkan adanya budaya partiarki yang seharusnya (Prasetyo, 2017). Terlihat dalam sineton ini, media mengkontuksikan laki-laki yang mandiri dalam rumah tangganya. Sinetron komedi yang mendapatkan penghargaan Indonesia Televison Awards 2017 sebagai program prime time drama terpopuler ini membuktikan bahwa, peminat untuk menonton sinetron ini terbilang cukup banyak (https://celebrity.okezone.com).

Penelitian terdahulu yang digunakan dalam penelitian ini berjudul: Karakter Perempuan Dalam Televisi (Analisis Resepsi Peran Istri Sebagai Tulang Punggung Keluarga Dalam Program Sitkom "Tetangga Masa Gitu" Di Net TV) dari penelitian Dian Prasetyo tahun 2017. Hasil dari penelitiannya memperlihatkan interpretrasi khalayak dalam memaknai media sangatlah beragam. Keseluruhan lebih memilih menegosiasikan segala sesuatu bentuk konstruksi media dengan pengalaman yang dilaluinya, karena sangatlah berbeda ketika aturan tertulis diterapkan dalam praktek (Prasetyo, 2017).

Penelitian lain dilakukan oleh Yeni Karlina tahun 2008, yang meneliti bagaimana 
dekontruksi stereotip perempuan dalam sinetron komedi (Analisis Semiotik Pada Sinetron Komedi Suami-suami Takut Istri Episode "Pesulap Salah Alamat" dan "Bantuan Banjir Bikin Tajir"). Hasil dari penelitian ini yaitu: pertama, dekontruksi stereotip terjadi dalam cara berpakaian, sifat dan peranan domestik yang dilakukan perempuan. Kedua, semua dekontruksi yang ada merupakan dekontruksi semu yang pada akhirnya merubah stereotip negatif pada perempuan. Ketiga, terdapat ideologi patriarki yang melatar belakangi setiap adegan dalam sinetron komedi ini (Karlina, 2008).

Perbedaan penelitian ini dengan penelitian sebelumnya yang dilakukan (Karlina, 2008) yaitu menganalisis semiotik pada sineton, sedangkan pada penelitian (Prasetyo, 2017) menganalisis resepsi peran istri atau karakter perempuan dalam sinetron. Penelitian ini juga mempunyai kesamaan dengan kedua penelitian sebelumnya yaitu adanya kontruksi peran gender yang ditayangkan oleh media massa terutama televisi pada program sinetron.

Pertanyaan utama dari penelitian ini adalah untuk melihat bagaimana khalayak meresepsikan peran laki-laki sebagai pekerja rumah tangga dalam program sitkom Dunia Terbalik. Penelitan ini juga diharapkan dapat membantu penelitian yang serupa mengenai analisis resepsi dan pengembangan ilmu komunikasi. Serta diharapkan mampu menghasilkan dan menjelaskan bagaimana karakter lakilaki sebagai suami yang berperan menjadi pekerja rumah tangga dalam program sinetron komedi Dunia Terbalik di RCTI dengan sudut pandang penonton dari latang belekang yang beragam.

\section{B. TINJAUAN PUSTAKA}

\section{Televisi sebagai Pengkonstruksi Peran Gender}

Televisi selalu menampilkan programprogram yang diminati masyarakat, bahkan televisi komersial sangat melekat pada masyarakat yang didorong oleh keinginan untuk menonton karya menarik yang dibuat secara normatif dalam studi media (McQuail dalam First, 2016). Sinetron hadir sebagai bentuk audiovisual, sehingga sinetron dapat memberikan pengalamanpengalaman baru kepada penontonnya yang menyampaikan berbagai aspek seperti nuansa pemikiran, perasaan, dan sikap (Khairiyah, 2013). Sinetron sendiri diperkenalkan oleh Soemardjono salah satu seorang pendiri dan mantan pengajar Institut Kesenian Jakarta, yang mengistiahkan sinetron dengan, sandiwara bersambung yang disiarkan oleh televisi (Saefudin dalam Mooy, 2015).

Drama/sinetron memiliki dua jenis (Suban dalam Mooy, 2015) yaitu: pertama, drama seri merupakan drama dengan menggunakan karakter yang sama akan tetapi dengan cerita yang berbeda setiap episodenya, yang bermaksud setiap cerita selesai dalam satu episode tetapi karakternya sama. Kedua, drama serial yang memiliki karakter yang sama dalam sebuah cerita dengan episode-episode yang panjang atau banyak.

Kata serial memiliki perbedaan dengan series, dalam suatu artikel yang dapat dibaca di website (https://belajarbahasa. id) mengatakan bahwa, serial merupakan kata yang menunjukan serangkaian cerita dengan subjek yang sama, namun satu cerita tersebut bukan untuk melanjutkan cerita sebelumnya dan menampilkan topik yang berbeda. Sedangkan series kata yang digunakan untuk menunjukan dimana satu cerita menjadi serangkaian cerita yang saling berkaitan.

Televisi sendiri merupakan media massa yang dapat membentuk kontruksi gender pada masyarakat. Karena media meiliki karakteristik dengan jangkauan yang luas dan bisa menjadi alat yang efekstif dalam mengkontuksi gender pada masyarakat (Hariyanto, 2009). Gagasan yang diberikan oleh media lewat sinetron, mempunyai kesempatan untuk dipahami oleh khalayak. Stereotip maskulinitas dan feminintas memang sering menjadi bagian paling 
populer pada program televisi (Marghitu, 2015).

\section{Kontruksi Gender dari Masyarakat}

Demartoto dalam Wandi (2015) menyatakan secara umum maskulinitas yang dicerminkan dengan kekuatan, kekuasaan, aksi, kemandirian, kepuasan diri, dan kerja adalah nilai-nilai utama pada lakilaki. Sedangkan hal yang dipandang rendah adalah masalah hubungan interpersonal, kemampuan verbal, kehidupan domestik, kelembutan, komunikasi, dan anak-anak dimana hal-hal tersebut dinilai sebagai sifat feminin dari perempuan.

Sedangkan dalam kehidupan kita mendominasi sistem budaya partiarki, membuat gender sebagai atribut yang diletakan secara sosial maupun kultural (Hariyanto, 2009). Gender dapat diartikan sebagai konsep sosial yang membedakan antara laki-laki dan perempuan. Pembagian peran, sifat, maupun watak laki-laki dan perempuan dapat dipertukarkan, berubah dari masa ke masa, dari tempat adat satu ke tempat adat yang lain, dan dari kelas kaya kekelas miskin (Hariyanto, 2009).

Adanya paham yang membedakan posisi laki-laki dan perempuan telah mengakibatkan terjadinya pembagian tugas di sektor domestik yang di dalam kehidupan rumah tangga dan sektor publik yang di luar kehidupan rumah tangga. Budaya partiarki masyarakat Jawa menunjukan juga bahwa seorang laki-laki/suami adalah kepala rumah tangga yang bertanggung jawab atas kehidupan di dalam keluarganya, terutama untuk mencari nafkah (Budiati, 2010). Sedangkan peran perempuan dalam rumah tangga sebagai yang mendidik anak, memasak, serta melayani suami.

Kegiatan yang diperuntukan bagi lakilaki/suami sebagai pencari nafkah, jika perekonomian dalam keluarga sangat terbatas, maka tidak dipungkiri perempuan/ isrtri ikut menjamah dalam pekerjaan mencari nafkah yang dulunya hanya dilakukan oleh laki-laki/suami (Sulaiman dalam Yuniastuti,2014). Keterlibatan seorang istri/perempuan dalam pencarian nafkah dikeluarga, akan berpengaruh terhadap peran dan pola dalam pelaksanaannya dikehidupan keluarga.

Budaya partiarki masih berlanjut pada ranah agama. Sebagai salah satu elemen kebudayaan, agama memiliki campur tangan terhadap elemen lain. Marx dalam Wandi (2015) menyembutkan bahwa agama menjadi tempat pengaduan terakhir bagi manusia, namun perempuan juga ketertindas melalui ajaran atau tafsir dari ajaraan yang cenderung bersifat gender. Sedangkan dalam agama islam dalam surat An-Nisa' (4): 34 yang mengartikan, "istriistri yang kamu campuri diantara mereka, berikanlah mahar pada mereka dengan sempurna sebagai sebuah kewajiban", yang bermaksud memberitahu kepada para suami untuk memberikan mahar dan nafkah adalah hukum yang wajib setelah akad nikah yang telah disesuaikan dengan kesanggupan suami (Prasetyo, 2017).

\section{Resepsi Audiences}

Resepsi khayalak menajadi sangat relevan dalam pemikiran postmodren dan neoliberalisme pada milenium ketiga (First, 2016). Pemanfaatan teori reception analysis sebagai pendukung dalam kajian terhadap khayalak sesungguhnya hendak mendapatkan khalayak yang tidak semata pasif namun dilihat sebagai agen kultural yang memiliki kuasa tersendiri dalam menghasilkan wacana yang ditawarakn media (Adi, 2012).

Encoding dan decoding merupakan proses komunikasi massa, encoding sebagai kegiatan yang dilakukan oleh sumber yang menerjemahkan pikiran dan ide-idenya dalam suatu bentuk yang dapat diterima oleh pihak penerima, seperti seorang sutradara film yang mewujudkan imajinasinya dalam bentuk hasil filmnya. Sedangkan decoding merupakan penerimaan pesan dari orang lain berdasarkan resepsi, pemikiran dan pengalaman masa lalu (Prasetyo, 2017).

Menurut Hall, (dalam Reid \& Van Niekerk, 2016) khalayak melakukan decoding terhadap pesan media melalui 
tiga kemungkinan posisi, yaitu posisi hegemoni dominan, negosiasi dan oposisi.

a. Posisi hegemoni dominan (dominant hegemonic position)

Hall menjelaskan hegemoni dominan sebagai situasi dimana pembaca sejalan dengan kode-kode dari media, yang di dalamnya tertera kandungan nilai-nilai, sikap, keyakinan dan asumsi. Secara penuh media menyampaikan pesan, dan pembaca dapat menerima pesan yang disampaikan secara positif.

b. Posisi negosiasi(negotiated position)

Posisi pembaca dalam batas-batas tertentu untuk sejalan dengan kode-kode media, akan tetapi pada dasarnya khalayak menerima makna yang diberikan media namun memodifikasikannya sedemikian rupa sehingga sesuai dengan keinginan atau minat pribadi.

c. Posisi oposisi( oppositional position)

Pembaca tidak sejalan dengan kodekode yang diberikan oleh media, atau pembaca sangat menolak makna yang diberikan oleh media dan mencoba untuk menentukan frame alternatif sendiri dalam menginterpresentasikan pesanmya.

Dengan teori respon yang bervariasi, akan tetapi dapat memberikan pelajaran yang bermanfaat tentang interpresentasi sasta yang terjadi bagi mempengaruhi baik pembaca dan penulis. Sedangkan faktor usia, jenis kelamin, etnis, konteks sosial, atau latar belakang ras juga dapat dikelompokan bersama-sama dan disebut secara garis besar oleh teori respon dan seluruhnya (Brooks \& Browne, 2012).

\section{METODE PENELITIAN}

Penelitian ini menggunakan pendekatan kualitatif untuk menggali penafsiran dan pemahaman yang dirasakan subjek meliputi behavior, motivation, dan reception yang tergambarkan secara lisan dan taks (Moleong dalam Asmara, 2016). Metode yang digunakan peneliti adalah Focus Group Discussion.

Populasi penelitian yaitu laki-laki dan perempuan Indonesia yang pernah atau masih mengikuti sinetron Dunia Terbalik. Sedangkan sampel penelitian ditentukan menggunakan purposive sampling. Peneliti memiliki empat kriteria informan yang meliputi; pertama, yang pernah bekerja sebagai TKIITKW yang dipandang sebagai bagian dari masyarakat, memiliki pengalaman migrasi, serta memiliki gambaran yang lebih jelas tentang alasanalasan melakukan migrasi dan dampakdampaknya terhadap keluarga TKI/TKW (Wafirotin, 2013). Kedua, keluarga yang istrinya ikut ambil bagian dalam mencari nafkah. Ketiga, gender antara laki-laki dan perempuan, yang terbagi dalam perbedaan pembagian hak dan kewajiban sehingga peranan keduanya akan berbeda pula di masyarakat. Keempat, etnis budaya yang terdiri dari budaya Jawa dan Lampung dimana kedua budaya ini dinilai dapat mewakili budaya yang ada di Indonesia sera dapat saling bertukar pikiran dan makna antara orang yang berbeda budaya (Silvana \& Heryadi, 2013).

Pelaksanaan teknik wawancara FGD dilakukan dengan membentuk sebuah kelompok kecil yang berisikan 4 orang, sedangkan dalam kelompok besar dapat berisikan terdiri dari 12 orang dalam satu kelompok. Terdapat dua fokus grup yang terdiri dari 4 orang anggota dalam Fokus Grup A dan 4 orang anggota dalam Fokus Grup B yang terdiri dari kriteria yang berbeda. Pertama, 4 anggota informan Fokus Grup A terdiri dari kriteria, mantan TKI/TKW, laki-laki dan perempuan dengan adanya etnis Jawa dan Lampung. Kedua, 4 anggota informan Fokus Grup B terdiri dari istri/ibu rumah tangga yang berkerja serta bapak/suami yang semuanya berentis Jawa.

Analisis data dari penelitian ini akan dianalisis menggunakan model Miles dan Humberman, yang dilakukan dalam tiga langkah yaitu pertama, reduksi data dan penarikan kesimpulan atau verifikasi atas informasi yang diberikan informan 
dalam menjawab pertanyaan. Kedua, dilakukan proses pengelompokan atau pengkatagorian data berdasarkan hasil jawaban yang disampaikan informan agar memudahkan proses analisis. Ketiga, pengumpulan data dengan FGD akan menghasilkan rekaman, catatan, atau dokumentasi dari hasil diskusi dengan dilanjutkan pengambilan kesimpulan (Prasetyo, 2017). Triangulasi digunakan untuk memeriksa kebenaran informasi yang diberikan informan melalui wawancara (Nasution dalam Prasetyo, 2017). Dua triangulasi yang digunakan adalah triangulasi teori dan triangulasi data.

\section{HASIL DAN PEMBAHASAN}

\section{Penggambaran Karakter Laki-laki Sebagai Pekerja Rumah Tangga Yang Cukup Berlebihan.}

Setelah melakukan pengambilan data dengan FGD, peneliti kemudian menyaring data yang disampaikan oleh khalayak kemudian dikelompokan dan dimasukan dalam tiga hipotesis pembacaan David Morley. Terlepas dari resepsi khalayak, dari aspek gender, budaya, dan agama mengenai karakter laki-laki di Indonesia dalam media massa, terdapat aspek gender, budaya, dan agama di Indonesia yang sepaham dengan media, akan tetapi posisi khalayak menolak penuh konstruksi media atau menolak kode-kode dari media. Kodekode yang dimaksud yaitu meliputi asumsi, sikap, keyakinan dan nilai-nilai (oppositional reading). Aspek-aspek yang menjadi penolakan penuh tersebut meliputi karakter laki-laki yang menurut resepsi khalayak Indonesia mempunyai sifat keibuan, inferior, pandai memasak, membereskan rumah, mengurusi kebutuhan anak dirumah, dan takut terhadap isrti, menurut resepsi khalayak dari isi tayangan Dunia Terbalik.

Sifat di atas merupakan karakter lakilaki yang muncul secara langsung dari resepsi khalayak secara subjektif ketika melihat tayangan Dunia Tebalik. Resepsi yang dihasilkan di atas merupakan hasil dari proses encoding dan decoding dimana hasilnya bertolak belakang dari subordinasi. Subordinasi merupakan posisi superior yang identik dengan kaum lakilaki dan inferior yang identik dengan kaum perempuan. Laki-laki beranggapan dirinya yang berkuasa atau menjadi yang pertama dan perempuan merupakan yang nomor kedua (Prasetyo, 2017). Posisi superior dan posisi inferior dapat dilihat dan dibedakan saat laki-laki dan perempuan telah menikah.

Pernikahan adalah ikatan lahir batin antara seorang laki-laki dengan seorang perempuan sebagai suami istri dengan tujuan membentuk keluarga yang bahagia dan kekal berdasarkan Ketuhanan yang Maha Esa (Lestrai \& Putri, 2015). Secara umum, peran kepala keluarga bertugas mencari nafkah untuk memenuhi kebutuhan sandang, pangan dan papan. Peran ibu rumah tangga bertugas dalam semua urusan yang ada dirumah, seperti membereskan rumah, memasak dan mengasuh anak (Budiati, 2010).

Pola pembagian peran dalam keluarga dipengaruhi oleh banyak faktor antara lain seperti dari kebijakan yang dibuat dari pemerintah yang tertuang dalam berbagai peraturan yang terdapat kebijakankebijakan yang tidak berkeadilan gender dan mesin menganut ideologi partiarki dalam hukum di Indonesia (Rahayu dalam Lestari \& Putri, 2015). Ideologi patriarki mencirikan bahwa laki-laki merupakan kepala rumah tangga pencari nafkah yang terlihat dalam pekerjaan produktif di luar rumah, seperti pernyataan informan Fokus Grup A berikut :

... kalau saya kan saya yang jadi TKI... saya mulai sadar, saya ini kepala keluarga, saya sudah menjadi seorang bapak dan saya harus bisa merubah nasib keluarga saya mas, Pekerjaan apa saja akan saya lakukan, asalkan tidak ketergantungan lagi sama mertua, sama orangtua saya... Cuman sekarang kan udah bisa ngebuktiin ke anak saya, keorangtua saya kalau saya itu mampu, bisa menjadi seorang bapak yang bertanggung jawab mas... kalau dibandingkan sama yang di sinetron jelas enakkan yang di sinetronlah mas, cuma nunggu uang 
transferan dari istri, tapi pada kenyataan nggak ada yang seperti itu. Itu mah cuma di buat buat aja, nggak seperti kenyataannya (Informan \#3A, 28 tahun, laki-laki, mantan TKI, sudah penah menikah, Lampung).

Informan \#3A menyatakan, seorang suami harus bertanggung jawab dengan keluarganya, bagaimanapun keadaan dan permasalahan yang ada di dalam keluarga, suami harus bertanggung jawab. Seperti permasalahan keterbatasan ekonomi dalam keluarga, tetaplah suami yang bertanggung jawab untuk mencari nafkahnya. Seorang Suami atau laki-laki sebagai pencari nafkah utama dalam keluarga dan sebagai kepala rumah tangga (Lestari \& Putri, 2015).

Sementara peran suami sebagai kepala rumah tangga, tidak berarti suami tidak dapat membantu peran istri dalam pekerjaan domestik di dalam rumah. Suami yang memiliki pandangan peran gender tradisional cenderung tidak dapat menyesuaikan diri dengan peran istri di dalam rumah, beda hal dengan suami yang memiliki pandangan peran gender modern, yang memiliki kepercayaan lakilaki dan perempuan memiliki kesetaraan dan terdapat struktur pembagian kekuasaan yang fleksibel antara laki-laki dan perempuan (Lestari \& Putri, 2015).

Seperti yang ditayangkan sinetron Dunia Terbalik, peran suami dalam mengerjakan pekerjaan domestik di dalam rumah bukanlah sebagai menyesuaikan atau membantu pekerjaan domestik istri, melaikan dipertukarkan antara pekerjaan domestik dan pekerjaan publik yang seharusnya suami lakukan. Seperti pernyataan informan Fokus Grup A berikut :

... Berlebihan mas menurut saya.. soalnya saat saya menjadi TKW di Taiwan mantan suami saya itu ia tetap bekerja, walaupun hanya menjadi supir angkot... Kalau di Dunia Terbalik kan rata-rata suaminya ga ada yang kerja. Lebih memilih menjadi bapak rumah tangga, terus cuma menungguin uang transferan tiap bulan dari istrinya, dibolak balikin lah mas peran suaminya itu (Informan \#1A, 32 tahun, perempuan, mantan TKW, sudah menikah, Jawa ).

Kontruksi yang dilakukan oleh media massa mengenai peran laki-laki menurut informan itu berlebihan. Sebagai seseorang yang pernah bekerja sebagai TKW, informan \#1A dalam rumah tangganya suami tetaplah sebagai kepala rumah tangga yang semestinya. Pernyataan yang sama juga disampaikan oleh informan Fokus Grup A berikut :

... Ya suami tetep juga nyari nafkah untuk keluarga, mencari pekerjaan yang layak dan tetap, tidak mengandalkan saya yang bekerja sebagai TKW, bagaimanapun juga kan tidak selamanya saya bekerja sebagai TKW, ada batas waktunya juga... jadi pas saya pulang saya udah ada uang tabungan untuk keluarga, suami saya juga sudah mendapatkan pekerjaan yang lebih jelas juga. Coba itu kalau istrinya pada pulang ga pada kerja jadi TKW lagi [Dunia Terbalik], masa ia tetep istrinya yang cari kerja terus suaminya tetep ngurusin rumah kan aneh (Informan \#2A, 30 tahun, perempuan, mantan TKW, sudah pernah menikah, Jawa).

Pernyataan informan \#2A sama halnya seperti informan \#1A, sosok suami dalam keluarga tetaplah sosok yang bertanggung jawab dalam mencari nafkah, bukan mengandalkan istri untuk mencari nafkah. Istri bekerja hanyalah dipandang sebagai suatu usaha untuk membantu suami yang mempunyai penghasilan kurang mencukupi (Budiati, 2010).

Saat seorang istri memutuskan untuk bekerja, ijin dari suami sangat diperlukan dalam memutuskan kedudukan jabatan atau menentukan pekerjaan seperti apa (Budiati, 2010). Sebaliknya hampir tidak ditemukan ketentuan yang dikenakan pada suami untuk minta ijin istri ketika akan memutuskan kedudukan atau tugas tertentu dalam bekerja. Hubungan keluarga yang harmonis ialah hubungan yang selalu melakukan musyawarah antara anggota keluarganya (Lestari \& Putri, 2015). 
Sebagai kedudukan yang lebih tinggi di dalam rumah tangga, suami menjadi pengambil keputusan yang lebih baik dibandingkan anggota keluarga yang lain, karena laki-laki dianggap memiliki kekuatan fisik dan psikis (Suhandjati, 2017). Kekuatan fisik, laki-laki memiliki kondisi fisik yang lebih kuat daripada perempuan, menjadikannya lebih kuat bekerja, sehingga laki-laki dapat memberi nafkah, melindungi, dan memimpin keluarganya. Sedangkan Kekuatan psikis merupakan kemampuan akal dan ilmu laki-laki dalam berpikir yang secara praktis, serta memiliki keberanian, kekuatan, kemampuan dalam mengatasi kesulitan dan memiliki kepercayaan diri. (Ilyas dalam Suhandjati, 2017). Laki-laki memiliki kepercayaan diri yang lebih tinggi dibandingkan perempuan (Kusuma, 2016).

Budaya partiarki juga membawa karakter laki-laki menjadi sosok suami yang harus mencari nafkah dalam keluarga, yang memiliki kekuasaan, agresif dan kuat, ternyata bukanlah hal yang absolut melainkan dapat diperukarkan dengan karakter perempuan (Karlina, 2008). Maskulin yang ada pada diri laki-laki membuat laki-laki memposisikan dirinya lebih tinggi daripada perempuan baik sektor publik maupun dalam rumah tangga (Lestari \& Putri, 2015). Bahkan dalam budaya partiarki menempatkan lakilaki sebagai dominan dan menempatkan wanita sebagai subordinat, akan tetapi lakilaki sebagai dominan dapat menjadi lakilaki sebagi subordinat dalam media massa, yang dapat menimbulkan berbagai resepsi khalayak setelah melihatnya. Terlebih media massa mutlak sebagai agen sosial dalam persebaran stereotip (Zhang, 2015). seperti pernyataan informan dalam Fokus Grup A berikut:

... ya kalau melihat dari cerita sinetronnya ya ga pantes mas, masa suami kok sifatnya kayak gitu, ngambekan, cengeng udah kayak ibuibu beneran. Terus satu kampung suami ketergantungan sama istrinya... Setidaktidaknya laki-laki kan harus berusaha dulu dalam menafkahin keluarganya, sekalipun itu berdagang, jadi tukang ojek, tapi kan pulang-pulang membawa uang walaupun cuma sedikit... la mungkin dari sisi tayangannya [Dunia Terbalik] biar menarik aja ceritanya. la memang menarik, buktinya saya nonton, Cuma kalo ada suami yang harus kayak gitu saya ga suka juga mas (Informan \#4A, 32 tahun, laki-laki, bekerja, sudah menikah, Jawa).

Penyataan informan \#4A melihat ketidakpantasan karakter laki-laki yang dikontruksikan media massa, dimana karakter laki-laki memiliki sifat yang lemah, ngambekan, dan cengen. Karena pada umumnya laki-laki memiliki karakteristik yang identik dengan stereotip maskulin yang disebut laki-laki maskulin, jika karakteristik berlebihan disebut lakilaki super maskulin, jika kurang disebut laki-laki kurang maskulin atau laki-laki feminin (Darwin, 1999). Maskulin identik dengan kuat, pemberani, melindungi, dan mempunyai sifat pemimpin (Krissetyoningrum, 2014).

Media massa terus menerus mengkonstuksi dan menyebarkan budaya partiarki. Realita televisi memainkan peran penting dalam membentuk budaya. Ini melanjutkan praktik media yang telah lama menguatkan yang negatif dan menyesatkan (Tyree, 2011). Media massa memainkan peran laki-laki dan perempuan terkadang menimbulkan resepsi yang sepaham dan tidak sepaham dari khalayak dalam mengkontruksi laki-laki dan perempuan. Laki-laki memiliki kekuatan hukum dan ekomoni yang mutlak atas anggota keluaga (Mosse, 2002). Perempuan hanya sebatas pada wilayah domestik yaitu melayani dan mengurus rumah tangga (Budiati, 2010). Karakter yang ditampilkan dalam sinetron Dunia Terbalik merupakan karakter lakilaki yang jarang dikonstruksi oleh media massa pada umumnya. Laki-laki yang sering dijadikan sebagai ikon di televisi, adalah sebagai sumber acuan khalayak meresepsikan laki-laki yang ideal (Marghitu, 2015). Memainkan peran kunci dalam sosialisasi, khalayak mengunakan televisi 
untuk sebagai sumber informasi dalam membandingkan dirinya dengan oranglain dan belajar mengenai tempat mereka di dunia dan sosial (Peruta \& Powers, 2017).

Beberapa pernyataan informan di atas, informan meresepsikan termasuk dalam kategori oppositional reading. Dalam kategori ini, khalayak bisa saja paham dan mengerti yang ditampilkan oleh media massa, akan tetapi posisi khalayak menolak penuh konstruksi media atau menolak kode-kode dari media, namun realitas televisi tidaklah terlepas dari kepentingan entertainment semata (Parasetyo, 2017).

Program televisi khususnya, dapat menjadi alat informasi bagi penonton atau khalayak untuk mengukur pola perilaku yang tidak secara langsung diberikan secara sosial (Tyree, 2011). Informasi digunakan khalayak sebagai barometer dirinya di dalam masyarakat.

\section{Pola Pengasuhan Anak Yang Dilakukan Oleh Bapak Pekerja Rumah Tangga Dalam Sinetron Dunia Terbalik.}

Umumnya pengasuhan anak lebih difokuskan kepada ibu sebagai pengasuh dibandingkan ayah (Zulkaida \& Setiawati, 2007). Karena, ibu dipandang lebih memiliki ikatan batin yang lebih kuat dengan anak dibandingkan ayah. Ikatan batin yang kuat berasal dari waktu bersama dengan anak lebih banyak dibandingkan ayah, seperti dari dalam kandungan sampai menyususi. Kodrat perempuan adalah menstruasi, hamil, melahirkan dan menyusui yang merupakan ciptaan Tuhan yang tidak dapat diubah (Budiati, 2010). Seperti pernyataan informan Fokus Grup B berikut :

... tugasnya suami ia harus mencari nafkah mas, bukan ngurusin rumah atau ngurus anak. Beresin rumah sama anak mah udah urusannya istri itu mah... Suami ya fokus mencari nafkah... Padahal suami itu kepala keluarga loh, yang dipandang sebagai pemimpin keluarga, eh ini malah kepemimpinannya ga ada [Dunia Terbalik], malah kayak suami yang jadi ibu-ibu. untung aja ga ngelahirin juga suaminya hehe (Informan \#4B, 26 tahun, perempuan, bekerja, sudah menikah, Jawa).

Informan menyatakan seorang suami/ laki-laki tugasnya dalam rumah tangga merupakan pencari nafkah, dalam urursan pekerjaan domestik di dalam rumah dan mengasuh anak biarlah itu urusan seorang isrti/perempuan. Karena perempuan memiliki sifat feminin yakni mencangkup kepekaan perasaan, kesabaran, keuletan, irasionalitas, kesetiaan, sifat mengalah, dan lemah lembut (Krissetyoningrum, 2014).

Setiap keluarga memiliki cara tersendiri dalam mengasuh anaknya, baik secara pola asuh dari suami atau pola asuh dari istri yang mendapatkan peran lebih untuk mengasuh anak dibandingkan suami. Pola asuh yang diberikan kepada anak akan berimbas pada kepribadian anak. Kepribadian anak akan terbentuk, salah satunya dari pengashuan keluarganya terhadap anak tersebut, semakin baik pola pengasuhan anak tersebut semakin baik pula hasil yang dicapai nantinya (Rahman, 2014). Pola asuh merupakan aktivitas kompleks yang mencakup berbagai tingkah laku spesifik yang bekerja secara individual dan serentak dalam memengaruhi tingkah laku anak (Prayoga, 2013).

Menurut Martin \& colbert (dalam Prayoga, 2013), pola pengasuhan terhadap anak memiliki empat pola asuh yaitu, pertama pola asuh demokratis, dimana cara pengasuhan ini memiliki kontrol yang bersifat luwes, orangtua memberikan bimbingan dan mengarahkan untuk anak mengerti tentang mengapa ada hal yang boleh dilakukan dan ada hal yang tidak boleh serta komunikasi yang dilakukan terbuka dengan dua arah. Kedua pola asuh otoriter, dimana pola asuh ini orangtua terlalu mengontrol dan mengekang anak. Orang tua tipe ini juga tidak mengenal kompromi dan dalam komunikasi biasanya bersifat satu arah. Ketiga pola asuh liberal, dimana pola asuh ini memberikan pengawasan yang sangat longgar serta memberikan kesempatan pada anaknya untuk melakukan sesuatu tanpa pengawasan yang cukup dari orangtua. 
Keempat pola asuh tidak terlibat, Orang tua tipe ini pada umumnya memberikan waktu dan biaya yang sangat minim pada anak-anaknya, serta waktu mereka banyak digunakan untuk keperluan pribadi mereka, seperti bekerja, dan juga kadangkala biaya pun dihemat-hemat untuk anak mereka.

Sinetron Dunia Terbalik yang mengkontruksikan peran laki-laki sebagai pekerja rumah tangga, selain mengerjakan pekerjaan domestik, para laki-laki/suami di Dunia Terbalik juga mengasuh anak tanpa adanya seorang istri (http://mncpictures. com). Karakter Akum salah satu aktor pemeran di Dunia Terbalik, sebagai seorang suami yang memiliki anak perempuan, cara pola pengasuhan anak yang dilihatkan di Dunia Terbalik terbilang lebih mengotrol dan mengekang anak atau pola asuh otoriter. Sebagai informan yang pernah bekerja sebagai TKW, informan memiliki pola asuh sendiri seperti pernyataan berikut:

... Nanti kalo suami juga yang pengang ngurusin anak, malah ga kepegang semua urusannya, yang harus kerja, yang harus nyiapin keperluan anak, keteteran yang ada semua, jadi ya biar sama orangtua saya aja, biar suami sama saya fokus bekerja, kan uangnya buat anak juga, kalo ada apa-apa ya saya paling tinggal telpon langsung keanaknya, nanya kabar ada masalah disana apa enggak, ia gitu aja mas. Kalo di Dunia Terbalik kan, bapaknya langsung yang turun tangan, ada apa apa bapaknya yang nyiapin, itu contohnya si akum, ada apa apa bapaknya yang turun tangan (Informan \#2A, 30 tahun, perempuan, mantan TKW, sudah pernah menikah, Jawa).

Peryataan informan melihatkan pola asuh yang diterapkan masuk dikatagori pola asuh tidak terlibat, yang merupakan orangtua menggunakan waktu mereka lebih untuk keperluan pribadi seperti bekerja (Prayoga, 2013). Informan yang bekerja sebagai TKW, tidak memiliki kesempatan penuh dalam mengontrol pola asuh anak. Informan lebih menyerahkan pengasuhan anaknya kepada kedua orangtuanya, karena suami dari informan pun sibuk dengan pekerjaannya.

Dengan apa yang telah ditayangkan Dunia Terbalik, cara pola asuh anak memiliki perbedaan yang diterapkan di dunia nyata. Sebagai pengalaman hidup yang dimiliki informan, informan memiliki pola asuh tidak terlibat, sedangkan disinetron Dunia Terbalik pola asuh yang diperlihatkan seorang ayah dengan pola asuh otoriter. Menjadi ayah merupaka proses yang menatang bagi laki-laki, dimana proses ini menyebabkan berbagai gejolak emosional, karena para ayah tidak terbiasa dalam afeksi yang kompleks yang muncul dalam hubungan antara ayah dan anak (Zulkaida \& Setiawati, 2007). Gejolak emosional yang dialamin laki-laki membuat pola asuh otoriter yang diterapkan dengan anak yang penuh tekanan dan lebih mengontrol anak.

\section{Peran Laki-laki Sebagai Pekerja Rumah Tangga Dari Perspektif Budaya Indonesia.}

Budaya Jawa adalah budaya yang memiliki pengaruh kuat untuk mempengaruhi budaya diwilayah lain. Seperti diwilayah Lampung, prosentase terbesar penduduknya adalah suku pendatang, yang sebagian besarnya adalah pendatang dari Jawa (Djausal, Handayani \& Ratnasari, 2017). Budaya Jawa merupakan budaya kerajaan dimana para raja sangat kental dengan gaya kepemimpinan yang absolutisme. Oleh sebab itu sebagai seorang raja dan kepala negara segala sesuatu kebijakannya haruslah berlaku dan diterima bagi semua lapisan masyarakat diberbagai wilayah. Oleh karenanya budaya Jawa cenderung tidak demokratis (Handayani \& Novianto, 2004).

Pemaknaan mengenai keberadaan laki-laki adalah kontruksi budaya partiarki yang dihasilakn dari budaya Jawa. Jawa sendiri menjadi perwakilan budaya lain di Indonesia untuk mencerminkan budaya patriarki yang ada di wilayah Indonesia, seperti wilayah Lampung, Sulawesi dan beberapa wilayah lainya di Indonesia (Hermawati dalam Prasetyo, 2017). Adanya anggapan bahwa laki-laki adalah pelindung bagi kaum perempuan, karena 
perempuan memiliki sifat lemah, penakut dan ketergantungan dengan orang lain. Posisi ini membuat apa yang telah budaya partiarti maknakan terhadap peran laki-laki semakin benar. Sebagai pelindung, lakilaki dalam keluarga pantas untuk menjadi kepala keluarga dan pemimpin keluarga, sedangkan kedudukan perempuan yang memiliki sifat ketergantungan, kedudukan perempuan tergantung pada suami, harus tetap patuh dan taat pada perintah suami (Budiati, 2010). Seperti pernyataan informan dalam Focus Group B berikut :

... Dari turun menurun keluarga saya dan saya adalah anak pertama yang mempunyai adik perempuan, diajarkan untuk bertangung jawab dan melindungi adik saya yang perempuan... entah itu kebetulan atau disengaja oleh orang tua saya, saya merasa itu membuat saya menjadi laki-laki yang bertanggu jawab akan sesuatu hal.. Menjadi anak laki-laki yang kuat dan pemberani, menjadi anak yang sopan santun, penuh tatakrama. Sampai semua itu saya ajarkan juga kepada anak saya (Informan \#1B, 30 tahun, laki-laki, bekerja, sudah menikah, Jawa).

Pengaruh dan apa yang diajarakan oleh kedua orang tua, membuatinforman menjadi sosok laki- laki yang bertanggung jawab. Hal ini membuat informan menyadari apa yang telah diajarkan oleh kedua orang tuanya dulu sangat berpengaruh di kehidupannya sekarang, dan akan mengajarkan apa yang telah diajarkan orang tuanya kepada anakanaknya juga.

Seorangbapakdanibuakanmenentukan karakter anak saat dewasa, dalam budaya Jawa sebagai wahana pendidikan moral anak, mengutamakan sopan santun/unggah ungguh, tepo selira, ewuh pekewuh antar manusia dengan manusia, manusia dengan alam (Widiyanti, 2013). Budaya Jawa menempatkan perempuan sebagai peran utama dalam mendidik anak, ikatan batin yang kuat dibangun saat ibu melahirkan, menjadi anggota keluarga yang sangat dekat dengan anak. Bapak atau suami dalam budaya jawa menepatkan suami menjadi anggota keluarga yang mencari nafkah (Budiati, 2010).

Tidak jauh beda dengan budaya Jawa, budaya Lampung menempatkan laki-laki adat Lampung dalam peran kepemimpinan dan pengambilan keputusan atas diri perempuan. Bagi Masyarakat Lampung, Perempuan sangat berperan dalam segala kegiatan, khususnya dalam kegiatan rumah tangga dan seorang ibu yang mencintai anak-anaknya (Djausal, Handayani \& Ratnasari, 2017). Seperti peryataan seorang informan asal Lampung Fokus Grup A berikut :

... kalau dari saya, saya kan orang lampung tidak jauh bedalah dari orangorang jawa juga, ga ada laki-laki jadi ibu ruamh tangga itu, laki-laki ya jadi kepala rumah tangga.. jadi laki-laki yang bertanggung jawab, kerja mencari nafkah untuk keluarga gitu baru bener laki-laki mas (Informan \#3A, 28 tahun, laki-laki, mantan $\mathrm{TKI}$, sudah pernah menikah, Lampung).

Pernyataan dari informan tentang peran laki-laki antara dua budaya yaitu budaya Jawa dan budaya Lampung tidaklah jauh beda. Peran laki-laki dalam keluarga dari dua budaya yang berbeda tetaplah lakilaki yang menjadi kepala keluarga dan pencari nafkah, akan tetapi dalam urusan memasak, membersihkan rumah atau mengasuh anak, laki-laki tidak pandai dalam melakukannya. Laki-laki tetaplah membutuhkan perempuan dalam rumah tangga, karena dalam menghadapi masalah praktis di dalam rumah, laki-laki cenderung tidak mahir untuk mengerjakannya serta lebih bekerja secara imajimatif (Handayani \& Novianto dalam Prasetyo, 2017).

Persoalan dalam rumah tanggalah yang membuat laki-laki bergantung dan butuh peranan perempuan sebagai figur pelengkap dalam rumah tangga (Prasetyo, 2017). Sebagai perempuan/istri tidak hanya dalam urusan memasak, membereskan rumah dan mengasuh anak, akan tetapi istri dapat membantu suami dalam urursan mencari nafkah dikala perekonomian keluarga sedang terbatas. Meskipun 
pekerjaan apa saja yang dihasilkan oleh perempuan/istri, hanyalah dipandang sebagai sambilan atau sebagai tambahan dalam memenuhi kebutuhan dalam keluarganya(Budiati,2010). Istriyang bekerja tetaplah sebagai istri yang seharusnya, tidak melupakan pekerjaan rumah yang harus menjadi kewajiban seorang ibu/istri. Seperti pernyataan informan Fokus Grup B berikut :

... Mungkin kalau aku yang menjadi TKW, ya mungkin suami aku juga akan mandiri hidupnya terus ngurusin anak juga, karena kan disini cuma aku, suami sama anak, saudara jauh, ibu bapak aku mertua jauh juga. Tapi ya kalau dari budaya aku, ga ada ya mas (bertanya sama suaminya) istri yang menjadi pencari nafkah utama yah. aku aja walaupun sembari kerja, tetap suami aku mas yang jadi kepala keluarga terus jadi pencari nafkah utama dia juga, aku juga tetap menjalani tugas aku sebagaimana seorang isrti pada umumnya, tidak melepas tugaskan tugas rumahnya sampai tidak mengurus anak (Informan \#4B, 26 tahun, perempuan, bekerja, sudah menikah, Jawa).

Informan yang memiliki pengalaman sebagai seorang istri yang bekerja, informan menyatakan walaupun sebagai istri yang bekerja, informan tetaplah seorang ibu/ isrti di dalam rumah, yang melayani suami, mengurus anak, membereskan rumah. Meyadari posisinya sebagai seorang istri, informan tetap menganggap suami adalah kepala keluarga dan pencari nafkah utama di dalam keluarganya (Budiati, 2010). Stereotipe budaya Jawa dan ajaran agama yang dibawa oleh informan menjadi satu pegangan hidupnya dalam menjalani peranya sebagai seorang istri.

Tayangan sinetron Dunia Terbalik membuat karakter laki-laki menjadi pekerja rumah tangga, yang mengerjakan semua pekerjaan di dalam rumah. Seperti memasak, membereskan rumah dan mengurus anak. Kontruksi dari media massa ini menukarkan kedua peran dalam rumah tangga, seperti pernyataan dari informan Fokus Grup A berikut :
... beda sama suami, suaminya harus menjadi kepala keluarga, mencari nafkah kewajibannya, berkerja keras, ini malah di sinetronya dibolak-balik ceritanya... Yang seharusnya suami seperti apa [kepala keluarga] yang istri juga seperti apa [ibu rumah tangga], ia minimal walaupun ditinggal istri kerja ke luar negeri, ya suami tetap bekerja juga lah mas... Judunya aja udah dunia terbalik, ia semuanya kebalik mas (Informan \#4A, 33 tahun, laki-laki, bekerja, sudah menikah, Jawa).

Informan sebagai suami meliat kontruksi di sinetron Dunia Terbalik menyatakan bahwa, sebagai suami yang ditingal istri bekerja setidaknya tetaplah bekerja, karena sebagai laki-laki yang miliki kedudukan yang dominan dari pandangan sosial, lingkungan dan budaya, laki-laki tetaplah kepala keluarga di dalam rumah yang bertanggung jawab segala sesuatu yang terjadi di dalam rumah. Agama islam pun bahkan mengajarkan bahwa, istri mendapatkan hak-haknya yaitu hak untuk mendapatkan penghormatan dari anak, hak untuk dicintai lebih dari seorang ayah, hak untuk didoakan, dan hak mendapatkan nafkah dari suami, tertulis dalam Al-quran surat Al-Luqman ayat 15 (Warsito dalam Prasetyo, 2017).

Seorang laki-laki memiliki otoritas hukum dan ekonomi yang mutlak atas anggota keluarganya (Mosse dalam Prasetyo, 2017). Demikian juga dalam ajaran agama Islam yang mengakatakan bahwa otoritas tertinggi dalam sebuah rumah tangga adalah laki-laki atau seorang suami. Suami memiliki tanggung jawab penuh atas istri dan anak-anaknya baik secara batin dan lahir (Warsito dalam Prasetyo, 2017).Suami juga memiliki otoritas dalam memutuskan sesuatu hal dalam rumah tangga.

\section{E. KESIMPULAN}

Peneliti mengkategorikan penelitian ke dalam tiga kategori pembahasan. Pertama, penggambaran karakter laki-laki sebagai pekerja rumah tangga yang cukup berlebihan. Kedua, pola pengasuhan anak 
yang dilakukan oleh bapak pekerja rumah tangga dalam sinetron Dunia Terbalik. Ketiga, peran laki-laki sebagai pekerja rumah tangga dari perspektif budaya Indonesia.

Hasilnya memperlihatkan interpretrasi khalayak dalam memaknai media sangatlah beragam. Dalam hasil penelitiannya, katagori resepsi oppositional reading lebih sering diguanakan ketika khalayak meresepsikan kontruksi media mengenai karakter laki-laki sebagai pekerja rumah tangga dan menghasilkan perbedaan dalam pola pengasuhan anak di dalam sinetron dan di dunia nyata. Fokus Grup A yang terdiri dari kualifikasi mantan TKW/ $\mathrm{TKI}$, beragama Islam, serta berasal dari etnis Lampung dan Jawa.

Pemaknaan khalayak mengenai konstruksi media masuk dalam hipotesi resepsi oppositional reading. Media menampilkan karakter laki-laki sebagai pekerja rumah tangga seperti memasak, membereskan rumah dan mengasuh anak, merupakan konturksi media yang berlebihan. Karena dalam realitanya suami dari istri yang bekerja sebagai TKW tetap suami yang menjadi kepala keluarga, dimana menjadi suami yang bertanggung jawab dengan tetap mencari nafkah dan tidak ketergantungan dengan istri yang bekerja sebagai TKW, meski kadang penghasilan istri lebih besar dibandingkan suami. Istri tetap memposisikan suami sebagai kepala keluarga di dalam rumah dan tidak menjadikan dirinya lebih dominan daripada suaminya.

Sedangkan dalam kategori perspektif budaya Indonesia, peneliti memiliki informan dari Fokus Grup A dan Fokus Grup $B$ yang memiliki dua budaya Indonesia yang berbeda, yaitu budaya Jawa dan budaya Lampung. Antara dua budaya ini mengandung budaya partiarki yang sama, dimana suami dalam rumah tangga adalah kepala keluarga dan istri adalah ibu rumah tangga. Tidak ada budaya partiarki yang menjadikan peran suami menjadi pekerja rumah tangga, seperti yang ditayangkan sinetron Dunia Terbalik dan masuk dalam katagori resepsi oppositional reading.

Peran suami sebagai pekerja rumah tangga disinetron Dunia Terbalik juga memilhatkan cara pola asuh anak. Pola asuh yang diperlihatkan Dunia Terbalik yaitu pola asuh anak otoriter, pola asuh ini sangatlah berbeda dengan pola asuh yang dirasakan langsung dari informan yang pernah bekerja sebagai TKW. Pola asuh anak yang diberikan informan lebih menunjukan kepada pola asuh anak tidak terlibat, dimana orangtua menggunakan waktu mereka lebih untuk keperluan pribadi seperti bekerja. Mengingat informan yang bekerja jauh dari anaknya, dan suami juga sibuk dengan pekerjaannya.

\section{DAFTAR PUSTAKA}

Adi, T. N. (2012). Mengkaji Khalayak Media dengan Metode Penelitian Resepsi. Acta diurnA, Vol. 8, No. 1, 26-30. Retrieved from www.komunikasi.unsoed.ac.id/

Asmara, L. R. (2016). Pria Barat Ideal Menurut Pandangan Khalayak Indonesia (Studi Pandangan Khalayak Indonesia Tentang Sosok Pria Barat Ideal Melalui Karakter Fiksi dalam Film Drama Romantis Hollywood). Surakarta: Universitas Muhammadiyah Surakarta, 5-10.

Browne, S., \& Brooks, W. (2012). Towards a Culturally Situated Reader Response Theory. Children's Literature in Education, 43(1), 74-85. Doi 10.1007/s10583-011-9154-z.

Budiati, A. C. (2010). Aktualisasi Diri Perempuan dalam Sistem Budaya Jawa (Persepsi Perempuan terhadap Nilai-nilai Budaya Jawa dalam Mengaktualisasikan Diri). Surakarta: Universitas Sebelas Maret, 1(3), 52-55. 
Dalyono, C. Teguh. (2010). Pengaruh Media Massa dan Pengetahuan Tentang Teknlogi Informatika Terhadap Pemanfaatan Teknologi Informatika dan Tingkat Modernitas Generasi Muda Kota Yogyakarta. Yogyakarta: Universitas Sanata Dharma Yogyakarta, Jurnal Ilmu Komunikasi, Vol. 8, No. 1, 86-92.

Djausal, Gita P., Handayani, Dwi W., \& Ratnasari, Yuni. (2017). Persepsi Laki-laki Lampung Tentang Partisipasi Perempuan dalam Politik. Lampung: Universitas Lampung.

First, A. (2016). Common Sense, Good Sense, and Commercial Television. International Journal of Communication. Netanya Academic College, Israel, 10, 533. Doi: 19328036/20160005. http://dx.doi.org/10.1080/10646175.2011.617217.

Hariyanto, (2009). Gender dalam Konstruksi Media. Puworkerto: STAIN Purwokerto, Vol. 3, No. 2. ISSN 1978-1261.

Karlina, Y. (2008). Dekonstruksi Stereotip Perempuan dalam Sinetron Komedi "Suami-suami Takut Istri" (Analisis Semiotik Pada Sinetron Komedi Suami-suami Takut Istri Episode "Pesulap Salah Alamat" dan "Bantuan Banjir Bikin Tajir"). Yogyakarta: Universitas Muhammadiyah Yogyakarta, 2-34.

Khairiyah, S. N. (2013). Analisis Produksi Terhadap Program Sinetron Tukang Bubur Naik Haji The Series (Episode 402 dan 403). Komunikasi dan Penyiaran Islam. Fakultas Ilmu Dakwah dan Ilmu Komunikasi. Universitas Islam Negeri.

Krissetyoningrum, Diyan. (2014). Dekonstruksi Maskulinitas dan Feminitas dalam Sinetron ABG Jadi Manten. Semarang: Universitas Diponegoro, 3-6.

Kusuma, R. S. (2016). Penggunaan Internet Oleh Dosen Berdasarkan Gender dan Generasi. Surakarta. Jurnal Komuniti. Penulis: Rina Sari Kusuma, M.I.Kom dosen Ilmu Komunikasi Universitas Muhammadiyah Surakarta, 3(1), 54-55.

Lestari, Sri \& Putri, Dyah Purbasari Kusumaning. (2015). PEMBAGIAN PERAN DALAM RUMAH TANGGA PADA PASANGAN SUAMI ISTRI JAWA. Surakarta: Universitas Muhammadiyah Surakarta, Vol. 16, No. 1, 2-5. ISSN 1411-5190.

Marghitu, S. (2015). Cable Guys: Television and Masculinities in the 21 st Century. International Journal of Communication, 9, 1-2. Doi: 1932-8036/2015BKR0009. Retrieved from http://doi.org/10.1177/0891243214558869.

Mooy, Ryzki Mentari Putri. (2015). Motif Dan Kepuasan Pemirsa Surabaya Dalam Menonton Sinetron "Tukang Bubur Naik Haji". Surabaya: Universitas Kristen Petra Surabaya, Vol. 3, No. 2, 5-6.

Peruta, A., \& Powers, J. (2017). Look Who's Talking to Our Kids: Representations of Race and Gender in TV Commercials on Nickelodeon International Journal of Communication, 11(0), 16. Doi: 1932-8036/20170005. Retrieved from http://ijoc.org/index.php/ijoc/ article/view/5113

Prasetyo, Dian. (2017). KARAKTER PEREMPUAN DALAM TELEVISI (Analisis Resepsi Peran Istri Sebagai Tulang Punggung Keluarga Dalam Program Sitkom "Tetangga Masa Gitu" Di Net TV). Surakarta: Universitas Muhammadiyah Surakarta, 6-10.

Prayoga, S. A. (2013). Pola Pengasuhan Anak pada Keluarga Orangtua Tunggal. Sosiologi. Fakultas Ilmu Sosial dan Politik. Universitas Lampung.

Raharto, Aswatini. (2017). Pengambilan Keputusan Tenaga Kerja Indonesia (TKI) Perempuan Untuk Bekerja di Luar Negri: Kasus Kabubaten Cilacap. Jurnal Kependudukan Indonesia, Vol. 12, No. 1. 39-54. ISSN 2502-8537.

Reid, R., \& Van Niekerk, J. (2016). Decoding Audience Interpretations of Awareness 
Campaign Messages. International Journal of Communication. 24(2), 177-193. Doi: 10.1108/ICS-01-2016-0003.

Reid, S. E. (2013). The Reality of Televised Jezebels and Sapphires: Blogs and the Negative Stereotypes of African American Women on Reality Television. Departement of Communication. Georgia State University, 9-11. Retrieved from http://scholarworks. gsu.edu/communication_theses.

Silvana, Hana., \& Heryadi, Hedi. (2013). KOMUNIKASI ANTARBUDAYA DALAM MASYARAKAT MULTIKULTUR (Studi Tentang Adaptasi Masyarakat Migran Sunda di Desa Imigrasi Permu Kecamatan Kepahiang Provinsi Bengkulu). Jakarta: Pusat Penerbitan Universitas Terbuka.

Suhandjati, Sri. (2017). KEPEMIMPINAN LAKI-LAKI DALAM KELUARGA: Implementasinya pada Masyarakat Jawa. Semarang: Universitas Islam Negeri Walisongo Semarang, , Vol. 28, No. 2, 329-350. http://dx.doi.org/10.21580/teo.2017.28.2.1876 ISSN 08533857.

Tyree, T. (2011). African American Stereotypes in Reality Television. Howard Journal of Communications, 22(4), 394-409. Doi: 10.1080/10646175.2011.617217. Retrieved from http://dx.doi.org/10.1080/10646175.2011.617217.

Wafirotin, K. Z. (2013). Dampak Migrasi Terhadap Kondisi Sosial Ekonomi Keluarga TKI Di Kecamatan Babadan Kabupaten Ponorogo. Ponorogo: Universitas Muhammadiyah Ponorogo, 11(2), 15-24.

Wandi, Gusri. (2015). Rekontruksi Maskulinitas: Menguak Peran Laki-laki dalam Perjuangan Kesetaraan Gender. Padang: lain Imam Bonjol Padang.

Zhang, L. (2015). Stereotypes of Chinese by American College Students: Media Use and Perceived Realism. International Journal of Communication, 9, 2-5. Doi: 19328036/20150005.

https://celebrity.okezone.com/read/2017/10/28/598/1804003/bawa-pulang-3-piala-pgadunia-terbalik-tetap-rendah-hati diakses pada tanggal 30 Januari 2018 pukul 01:02 WIB.

https://m.belajarbahasa.id/artikel/dokumen/278-perbedaan-antara-serial-danseries-2017-01-31-04-23 diakses pada tanggal 01 Januari 2018 pukul 22:01 WIB.

http://www.mncpictures.com/DUNIA-TERBALIK/index.html diakses pada tanggal 29 Januari 2018 pukul 22:28 WIB. 